\author{
J. Molero, A. M. Rovira, M. Bosch, J. Simon \& C. Blanché
}

\title{
Karyological study of the genus Aconitum (Ranunculacae) in the W Mediterranean Area
}

\begin{abstract}
Molero, J., Rovira, A. M., Bosch, M., Simon, J. \& Blanché, C. 2016: Karyological study of the genus Aconitum (Ranunculacae) in the W Mediterranean Area [In Kamari, G., Blanché, C. \& Siljak-Yakovlev, S. (eds), Mediterranean plant karyological data - 26]. - Fl. Medit. 26: 229-239. doi: 10.7320/FlMedit26.229

A karyological study of 38 populations belonging to 8 taxa of the genus Aconitum (Ranunculaceae) from the W Mediterranean Area is presented here. Karyotype microphotographs and corresponding idiograms for all taxa are provided and their karyotype morphology is discussed.
\end{abstract}

1885. Aconitum anthora $\mathrm{L} .-2 n=32$.

Ga: Pyrénées Orientales, Vall d'Eina, meadow, 42 26' 39" N 2०06' 55" E, alt. 2000 m, 20 Aug 1994, M. Bosch (BCN 4712).

Hs: Girona, Alta Garrotxa, Bassegoda peak, rocky scree, 42 $2^{\circ} 18^{\prime} 46^{\prime \prime} \mathrm{N} 2^{\circ} 37^{\prime} 51^{\prime \prime} \mathrm{E}$, alt. 1370 m, 22 Aug 1985, J. Molero \& A. Rovira (BCN 4718).

- Huesca, Lanuza, dam in the gorge of Portet, $42^{\circ} 45^{\prime} 32$ " N $0^{\circ} 17$ ' 42" W, alt. 1900 m, 28 Jul 1994, A. Salvador \& J. Vicens (BCN 4711) - Figs 1A \& 3A.

- Lleida, Llebreta Lake, Aigües Tortes-Sant Maurici, 42॰33'02” N $0^{\circ} 53$ ' 27' E, alt. 1750 m, 30 Aug 1994, J. Simon \& M. Bosch (BCN 4714). - Figs 1B \& 3B.

- Lleida, Vall d'Aran, above Arrós, ravine of Varradós, cottage of les Artiguetes to Salt del Pish, grasslands and wet meadows, $42^{\circ} 46^{\prime} 36^{\prime \prime} \mathrm{N} 0^{\circ} 50^{\prime} 05^{\prime}$ E, alt. $1500 \mathrm{~m}, 3$ Sept 1992, J. Molero \& A. Rovira (BCN 14360).

The five surveyed populations (Central \& E Pyrenees) share the same chromosome number $2 n=4 \mathrm{x}=32$ (Figs $1 \mathrm{~A}-1 \mathrm{~B}$ ), as previously reported in the few studies available from the Iberian Peninsula (Picos de Europa, Díez \& al. 1984) and French Pyrenees (Küpfer 1974; Baltisberger \& Utelli 2001) and in accordance with the previous counts known from European origin (Bosch \& al. 2016).

The haploid idiograms (Pyrenean populations, Figs 3A-3B) are quite similar, with the formula $2 n=13 \mathrm{sm}+3 \mathrm{st}=16$ chromosomes, slightly differing (length of long arm of pair II) from those reported by Seitz \& al. (1972) from the Jura massif (Ch). Some variation in number and position of satellites is detected: pair XIV (Pyrenees, present paper), pair V (Slovenia, Seitz \& al. 1972), pairs XIV and XV (Jura, Seitz \& al. 1972), as also observed in A. lycoctonum and particularly in the A. napellus-group (Figs. $3 \& 4$ ). Chromosome size and total karyotype length in $A$. anthora are clearly shorter than in the remaining groups, even considering the tetraploid condition (and thus losses and deletions), also detected by 


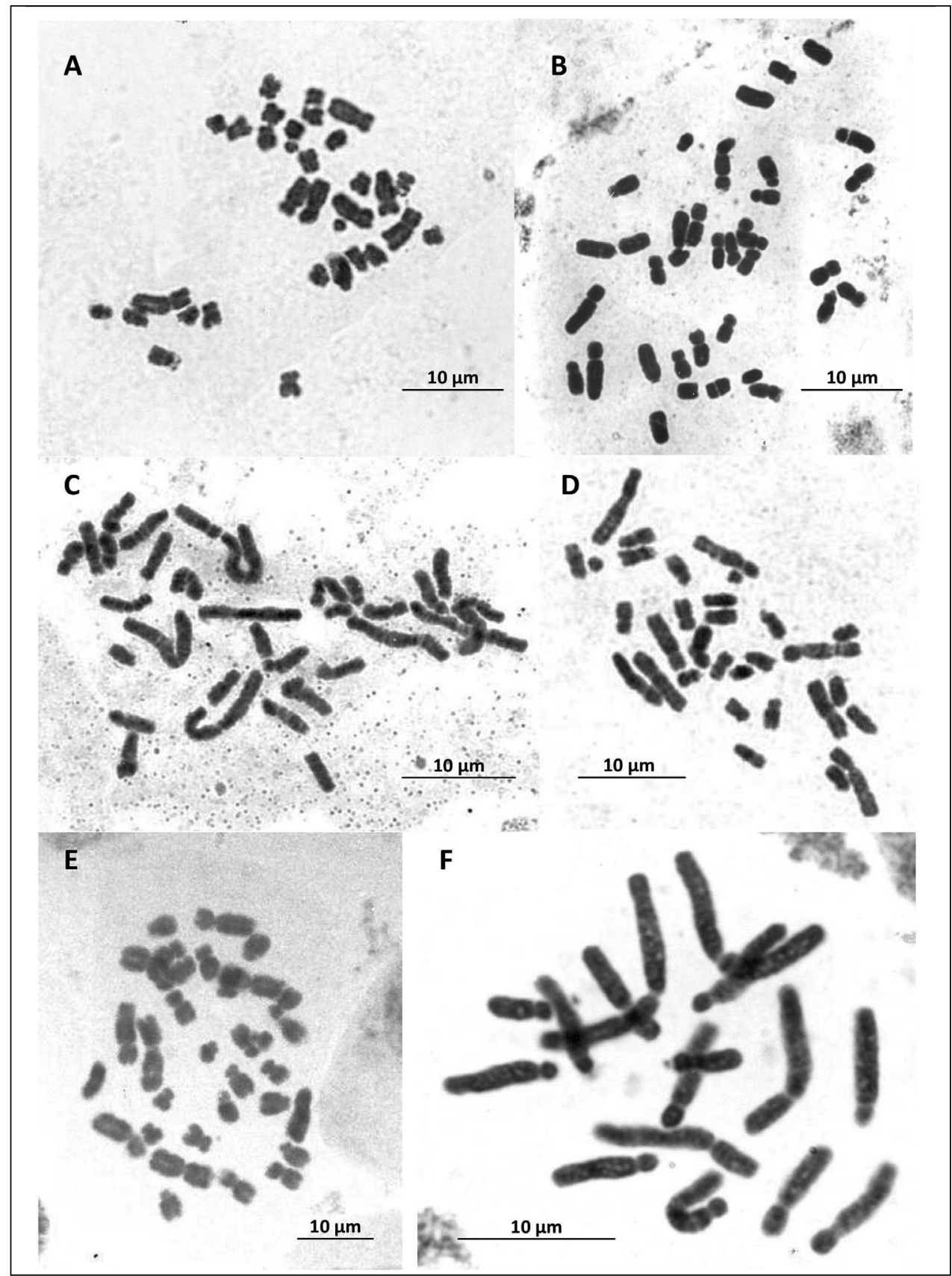

Fig. 1. Microphotographs of somatic metaphase plates of: A-B, A. antora, $2 n=32$ : A, Lanuza (Hs: Huesca) \& B, Llebreta Lake (Hs: Lleida); C-E, A. burnatii, $2 n=32$ : C, Authion (Ga: Alpes Maritimes), D, La Hoya de la Mora (Hs: Granada) \& E, Peña Oroel (Hs: Huesca); F, A. lycoctonum, $2 n=16$, Sierra Nevada (Hs: Granada). 
Schafer \& La Cour (1934) and Kočková (2012), this last one from DNA values. Seitz \& al. (l.c.) considered A. anthora as an old taxon originated by autopoliploidy from a diploid Asiatic ancestor; it has been placed by Jabbour \& Jenner (2012) in a clade of relatively old divergence.

1886. Aconitum burnatii Gáyer subsp. burnatii $-2 n=32$.

Ga: Alpes Maritimes, Madone de Fenestre, meadow near a stream, $44^{\circ} 05^{\prime} 41^{\prime \prime} \mathrm{N} 7^{\circ} 21^{\prime}$ 30” E, alt. 1910 m, 17 Sept 1993, M. Bosch, J. Simon \& J. Vicens (BCN 14362). - Fig. $3 \mathrm{C}$.

- Alpes Maritimes, Circuit d'Authion, gaunt ravine, 44 00' 07' N $7^{\circ} 25^{\prime} 49^{\prime \prime} \mathrm{E}$, alt. 1900 m, 17 Sept 1993, M. Bosch, J. Simon \& J. Vicens (BCN 14361). - Figs 1C \& 3D.

Hs: Granada, Sierra Nevada, Laguna de las Yeguas, source of a creek, $37^{\circ} 03^{\prime} 32^{\prime \prime} \mathrm{N} 3^{\circ} 22^{\prime}$ 50" W, alt. 2800 m, 27 Jun 1983, C. Benedí, C. Blanché, J. Molero, J. Molero-Mesa \& J. Vallès $(\mathrm{BCN})$. - Fig. 3E.

- Granada, Sierra Nevada, Hoya de la Mora, under the university refugee, $37^{\circ} 05^{\prime} 34^{\prime \prime} \mathrm{N}$ 3 23' 09" W, alt. 2500 m, 14 May 1986, J. Molero (BCN 4725). - Figs 1D \& 3F.

— Huesca, Jaca, Peña Oroel, under "Faixa Paco", 42॰31' 12" N 0 31' 47" W, alt. 1630 m, 1 Oct 1992, J. Molero \& A. Rovira (BCN 14359). - Figs 1E \& $3 \mathrm{G}$.

Our results included the first reports for W Mediterranean populations (Pyrenees, Sierra Nevada) of this taxon, with $2 n=4 \mathrm{x}=32$ chromosomes (Figs $1 \mathrm{C}$ to $1 \mathrm{~F}$ ). The only previously known European references come from Maritime Alps populations (Ga, It) under the name A. divergens subsp. burnatii (Gáyer) W. Seitz with indications of $2 n=32$ (Seitz 1969).

Also for the first time, five haploid idiograms belonging to A. burnatii subsp. burnatii are presented (Figs 3C to 3G), with karyotype structure corresponding to the A. napellus s.l.- type defined by Seitz (1969). These idiograms show minor differences in several pair ratios, whereas it seems relevant that the Iberian populations of $A$. burnatii (and also of the A. napellus grex) constantly bear the pair II shorter than pair I. The significance of variation in the II pair of chromosomes in tribe Delphinieae has been discussed in Blanché \& al. (1997). Satellite positions are shared by Maritime Alps and Pre-Pyrenees populations (pair XI), whereas in Sierra Nevada karyotypes they appear in pair XIII.

1887. Aconitum lycoctonum L. subsp. lycoctonum $-2 n=16$.

Hs: Ávila, Puerto de Mijares, near the edge of a stream, $40^{\circ} 19^{\prime} 52$ " N $4{ }^{\circ} 48^{\prime} 48^{\prime \prime} \mathrm{W}$, alt. $1570 \mathrm{~m}, 11$ Oct 1986, J. Molero (BCN).

- Granada, Sierra Nevada, near Parador Nacional to Veleta peak, $37^{\circ} 05^{\prime} 11^{\prime \prime} \mathrm{N} 3^{\circ} 22^{\prime}$ 25 " W, alt. 2500 m, 14 May 1986, J. Molero (BCN). - Figs 1F \& 3H.

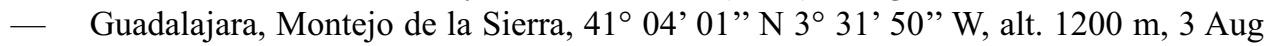
1985, C. Benedi \& J. Molero (BCN). - Fig. 3I.

- Huesca, Benasque, near Llosás, meadow, 42 36’34" N 0³0’ 21" E, 1 Aug 1993, alt. $2200 \mathrm{~m}$, M. Bosch \& J. Simon (BCN 14358). 


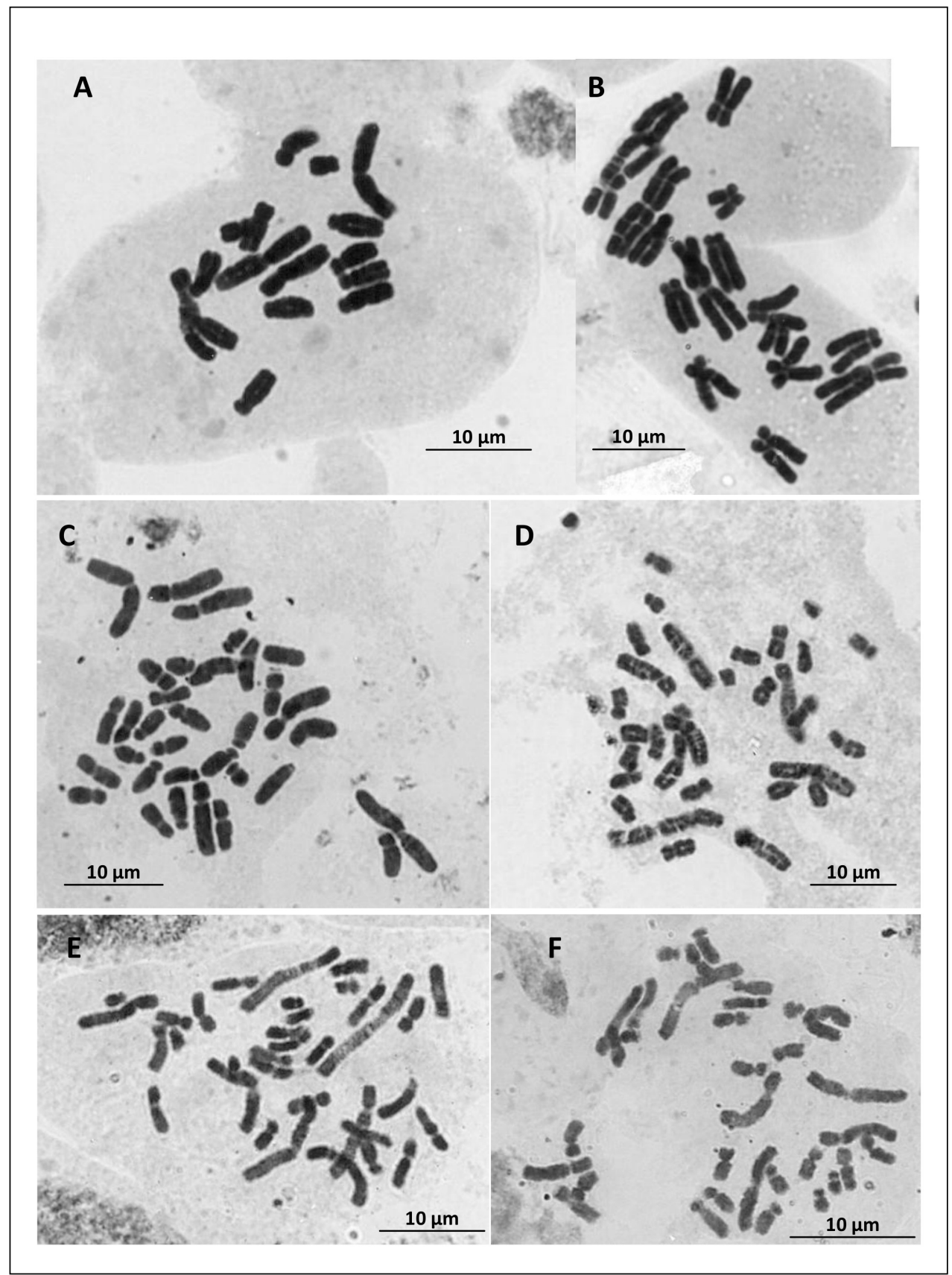

Fig. 2. Microphotographs of somatic metaphase plates of: A-B, A. lycoctonum subsp. lycoctonum, $2 n=16$ : A, Moncayo (Hs: Huesca) \& B, Oukaimeden (Ma: Haut Atlas); C-D, A. napellus subsp. castellanum, $2 n$ = 32: C, Laguna del Marquesado (Hs: Cuenca) \& D, Las Honfrias (Hs: Salamanca); E-F, A. napellus subsp. vulgare, $2 n=32$ : E, Lago Enol (Hs: Oviedo) \& F, Moncayo (Hs: Huesca). 
— León, Cofiñal, 43 01' 48” N 5 15' 58” W, alt. 1200 m, 19 Jul 1984, F. Llamas (BCN 4874).

- Oviedo, Puerto de Veguerada, between calcareous rocks, $43^{\circ} 02$ ' 38" N 5 29' 41", W, alt. 1500 m, 1 Jun 1994, C. Blanché \& J. Simon (BCN). - Fig. 3J.

- Soria, Sierra Cebollera, forest trail over Molinos de Razón, granitic scree in birch clearings, $41^{\circ} 58^{\prime} 23^{\prime \prime} \mathrm{N} 2^{\circ} 35^{\prime} 15^{\prime}$ W, alt. $1300 \mathrm{~m}, 16$ Aug 1983, J. Molero \& A. Rovira (BCN 4863).

- Zaragoza, Moncayo, Beratón, ravine slope, on stony and rich in humus ground near to A. napellus, $41^{\circ} 43^{\prime} 17^{\prime}$ ' N $1^{\circ} 48^{\prime} 18^{\prime}$ ' W, alt. $1480 \mathrm{~m}, 2$ Jul 1995, J. Molero \& A. Rovira (BCN 4766). - Figs 2A \& 3K.

Ma: Haut Atlas, Oukaimeden peak, margin of a stream, 31 ${ }^{\circ} 11^{\prime} 48^{\prime \prime} \mathrm{N} 7^{\circ} 50$ ' 02' W, alt. 2700 m, 20 Jun 1994, J. Molero, A. Rovira, C. Blanché, M. Bosch \& J. Simon (BCN). - Figs 2B \& 3L.

The nine studied populations from Spain and Morocco presented $2 n=2 \mathrm{x}=16$ chromosomes (Fig. 1F and Figs 2A-2B), as reported from many sources (Bosch \& al. 2016). The previously known numbers from $A$. lycoctonum Iberian populations -although published under several alternative nomenclatural combinations- are also $2 n=16$ (Küpfer 1974; Löve \& Kjellquist 1974; Baltisberger \& Charpin 1989; Baltisberger \& Utelli 2001 and Castroviejo \& al. 2003) as well as the North African ones (Galland 1988).

Only diploid cytotypes have been reported for A. lycoctonum, apart from a rare and old report of a triploid $(2 n=24$, Delay 1947). However, poliploidy has been documented in tetraploid and hexaploid Chinese species of Aconitum subgen. Lycoctonum (Yuan \& Yang 2006; Hong \& al. 2016): $2 n=32$ in A. angustius W.T. Wang, A. brevicalcaratum (Finet \& Gagnep) Diels, A. crassifolium Hand.-Mazz., A. chrysotrihum W.T. Wang, and A. rilongense Kadota, and $2 n=48$ in A. apetalum (Huth) B. Fedtsch ex Stein. The most deviant chromosome count in subgen. Lycoctonum is the very recently published $2 n=12$ from A. fletcherianum G.Taylor, with a karyotype showing deep and significant chromosome rearrangements (Hong $\&$ al. 2016), representing the first report of this chromosome number in the genus Aconitum.

We obtained the haploid idiogram for four Iberian populations and one from Morocco (Figs $3 \mathrm{H}$ to $3 \mathrm{~L}$ ). This taxon shows a very stable karyotype structure in its whole southern distribution area, from Romania to the Moroccan Atlas, in coincidence with that published by Seitz \& al. (1972), exhibiting a common chromosome formula $(2 n=2 \mathrm{~m}+6 \mathrm{sm}+8 \mathrm{st}=16$ chromosomes $)$. Minor differences in arm lengths of pairs II and VI should be noted, as well as the number of satellite pairs (one, VII or mainly VIII in Iberian and Moroccan populations, vs two, VII and VIII in the Romanian one). The characteristic relatively longer short arm of pair $\mathrm{V}$ found in A. lycoctonum (both subsp. lycoctonum Figs 3H to 3L and subsp. ranunculifolium, Figs 4A-4B) has been also reported from Chinese diploid species of this subgenus (Yuan \& Yang 2006; Hong \& al. 2016).

1888. Aconitum lycoctonum subsp. ranunculifolium (Rchb.) Schinz \& R. Keller $-2 n=16$.

Hs Girona, Vallter, over Setcases, megaphorbic communities on the bed of the valley, $42^{\circ} 44^{\prime} 21^{\prime \prime} \mathrm{N} 2^{\circ} 16$ ' 30" E, alt. 1800 m, 22 Aug 1985, J. Molero (BCN 4762).

- Huesca, Peña Montañesa, 42 30’ 00" N 0 12' 20” E, alt. 1500 m, 12 Aug 1985, J. 


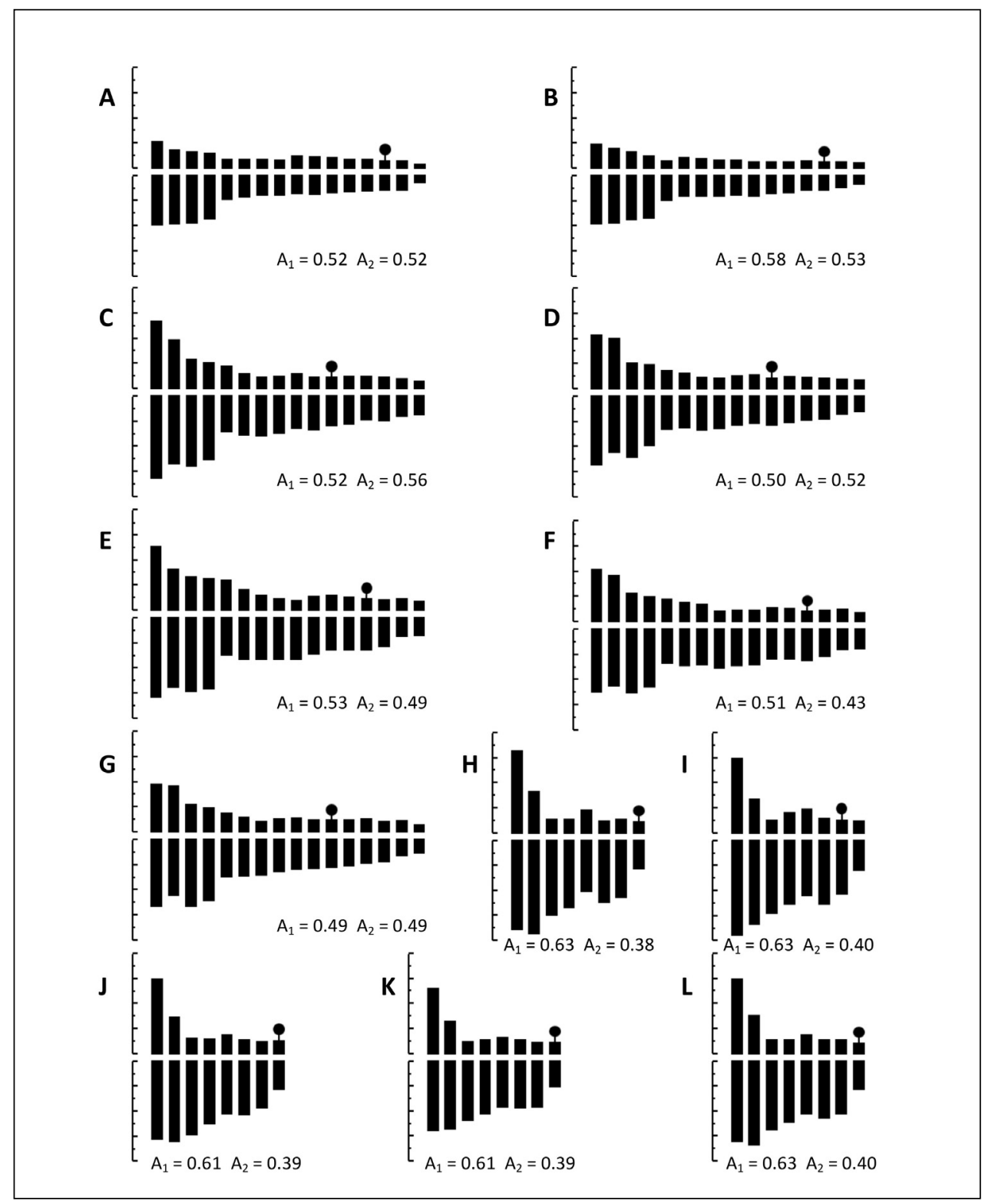

Fig. 3. Haploid idiograms obtained by measuring at least 5 good mitotic metaphases, 3 hours after pretreatment with colchicine $0.05 \%$. Asymmetry indices A1 and A2 are calculated following Romero (1986). A-B, A. antora: A, Lanuza (Hs: Huesca) \& B, Llebreta Lake (Hs: Lleida); C-G, A. burnatii: C, Madone de Fenestre (Ga: Alpes Maritimes), D, Authion (Ga: Alpes Maritimes), E, Laguna de las Yeguas (Hs: Granada), F, La Hoya de la Mora (Hs: Granada) \& G, Peña Oroel (Hs: Huesca); H-L, $A$. lycoctonum subsp. lycoctonum: H, Sierra Nevada (Hs: Granada), I, Montejo de la Sierra (Hs: Guadalajara), J, Puerto de Veguerada (Hs: Oviedo), K, Moncayo (Hs: Soria) \& L, Oukaimeden (Ma: Haut Atlas). - Scale bars $=8+8 \mu \mathrm{m}$. 
Molero (BCN). - Fig. 4B.

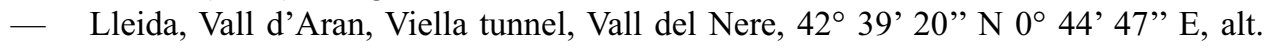
1600 m, 27 Jul 1994, J. Simon \& M. Bosch (BCN 4759). - Fig. 4A.

Three Iberian populations (from Catalonia and Aragon) are reported here for the first time, showing diploid cytotypes of $2 n=2 \mathrm{x}=16$. Only few and old chromosome data, coincident, are available for this taxon in Europe: Lovka \& al. (1971) from Slovenia and Seitz $\&$ al. (1972) from Italy (S Tyrol). Some authors (Akeroyd \& Chater 1993) place this taxon under the synonymy of $A$. lycoctonum; we follow the criteria of Seitz \& al. (1972), confirmed by Molero \& Blanché (1986).

Two haploid idiograms (from Central Pyrenees and Pre-Pyrenees) are presented (Figs 4A-4B). Karyotype structure is nearly identical between the two studied populations and the Iberian populations of subsp. lycoctonum $(2 n=2 \mathrm{~m}+6 \mathrm{sm}+8 \mathrm{st}=16$ chromosomes $)$. Minor variation in subsp. ranunculifolium refers to arms ratios (at the border of sm and st limits) and satellites presence: in pair VIII in Vall de Nera population, absent in Peña Montañesa.

1899. Aconitum napellus subsp. castellanum Molero \& C. Blanché $-2 n=32$.

Hs: Cuenca, Laguna del Marquesado, peaty soil, $40^{\circ} 10^{\prime} 40^{\prime \prime} \mathrm{N} 1^{\circ} 40^{\prime} 17$ " W, alt. 1400 m, 12 Oct 1986, J. Molero (BCN 4682). - Figs 2C \& 4D.

- Salamanca, Linares de Riofrío, Las Honfrias, in castanetis with Pteridium aquili-

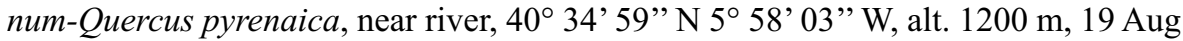
1985, C. Blanché \& R. Ferrer (BCN 4685). - Figs 2D \& 4E.

The somatic number of $2 n=4 x=32$ chromosomes (Figs 2C-2D), is given here for the first time for this endemism of the Centre of the Iberian Peninsula (Molero \& Blanché 1986), not differing from the remaining subspecies of the polymorphic complex of $A$. napellus s.1. (Bosch \& al. 2016).

The karyotype structure of the two studied populations (Figs 4D-4E) is analogous to the basic model described by Seitz (1969) for the subspecies of Aconitum grex. napellus found in Europe (Akeroyd \& Chater 1993), with some polymorphism at population level in subsp. castellanum: in arm ratio (pairs VI, XII, XV) and number of sat-chromosomes: two in Cuenca (VII and XII) vs. a single one (VII) in Salamanca.

1900. Aconitum napellus subsp. lusitanicum Rouy $-2 n=32$.

Hs: Ávila, Puerto Mijares, near the edge of a stream, 40 $19^{\prime} 58^{\prime \prime} \mathrm{N} 4^{\circ} 48^{\prime} 44^{\prime \prime} \mathrm{W}$, alt. $1680 \mathrm{~m}, 11$ Oct 1986, J. Molero (BCN 4691).

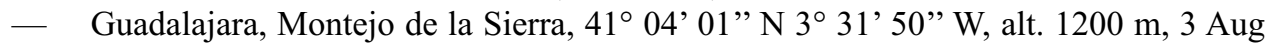
1985, C. Benedí \& J. Molero (BCN 4690).

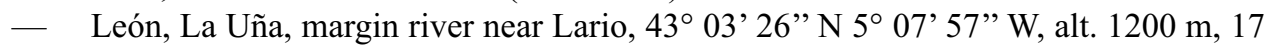
Aug 1985, C. Blanché \& R. Ferrer (BCN 4735). 
A

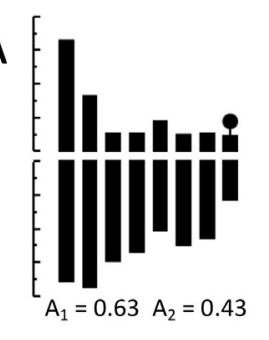

D

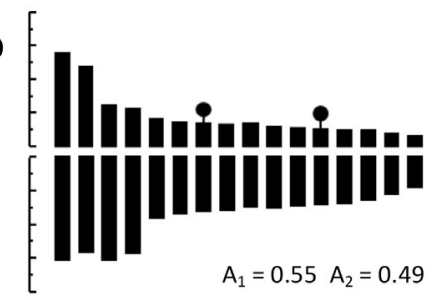

F

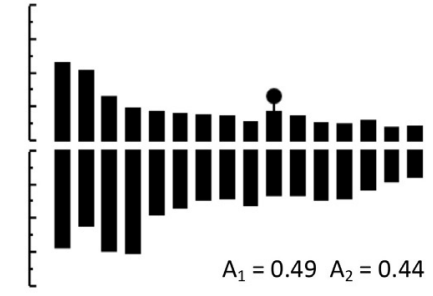

H

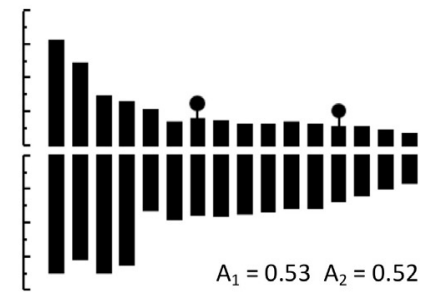

B

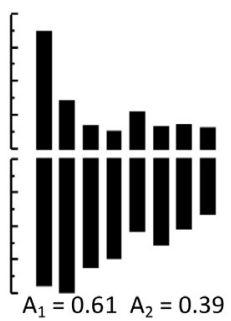

C

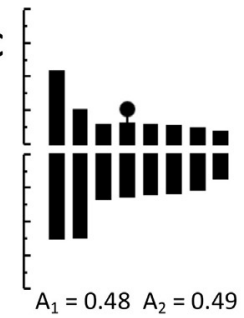

E

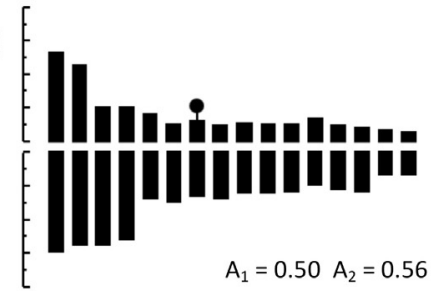

G

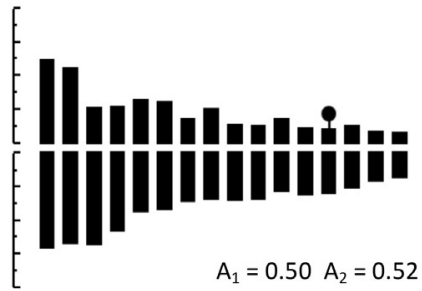

I

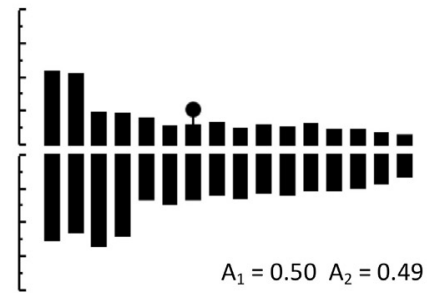

Fig.4. Haploid idiograms obtained by measuring at least 5 good mitotic metaphases, 3 hours after pretreatment with colchicine $0.05 \%$. Asymmetry indices A1 and A2 are calculated following Romero (1986). A-B, A. lycoctonum subsp. ranunculifolium: A, Vall del Nere (Hs: Lleida) \& B, Peña Montañesa (Hs: Huesca); C, A. variegatum subsp. pyrenaicum, Espelunguère (Ga: Pyrénées Atlantiques); D-E, A. napellus subsp. castellanum: D, Laguna del Marquesado (Hs: Cuenca) \& E, Las Honfrias (Hs: Salamanca); F-I, A. napellus subsp. vulgare: F, Valdegobia (HS: Álava), G, Valle de Ordesa (Hs: Huesca), H, Lago Enol (Hs: Oviedo) \& I, Moncayo (Hs: Soria). - Scale bars $=8+8 \mu \mathrm{m}$. 
— León, Villasecino, meadow near a creek, 42 $57^{\prime} 03^{\prime \prime} \mathrm{N} 6^{\circ} 01^{\prime} 36^{\prime \prime} \mathrm{W}$, alt. $1200 \mathrm{~m}$, 17 Jul 1984, J. Molero \& C. Blanché (BCN 4736).

— Palencia, a creek near Areños, 42 59' 57' N 4²9'34" W, alt. 1130 m, 15 Aug 1985, C. Blanché \& R. Ferrer (BCN 4741).

- Zamora, Alcorcillo, near Alcañices, alder forest, $41^{\circ} 42^{\prime} 39$ ' N 6 22 ' $10^{\prime \prime} \mathrm{W}$, alt. 600 m, 31 May 1994, C. Blanché \& J. Simon $(\mathrm{BCN})$.

First absolute records for the six Iberian populations of this taxon, where we obtained the somatic number $2 n=4 \mathrm{x}=32$. This result agrees with the counts reported by Seitz (1969) from several populations coming from Germany, Austria and N. France identified as A. napellus subsp. neomontanum (Wulfen) Gáyer, a non-priority synonym of the same taxon.

1901. Aconitum napellus subsp. vulgare (DC.) Rouy \& Fouc. $-2 n=32$.

Ga: Pyrénées Orientales, Vall d'Eina, orri de baix, grassland near a creek, $42^{\circ} 26^{\prime} 38^{\prime \prime} \mathrm{N}$ $2^{\circ} 06^{\prime}$ 56” E, alt. 1980 m, 18 Jul 1994, M. Bosch \& J. Simon (BCN 4732).

Hs: Álava, Valdegovia, 42 $2^{\circ} 50^{\prime} 55^{\prime} \mathrm{N} 3^{\circ} 04$ ' 24" W, alt. $600 \mathrm{~m}, 13$ Oct 1985, B. Fdez. de Betoño \& J. A. Alejandre (Alejandre Personal Herbarium). - Fig. 4F.

— Barcelona, Pedraforca, scree, 42 14 ' 13" N 1 42’ 16” E, alt. 2300 m, 22 Sept 1985, C. Blanché (BCN 4740).

- Girona, Vallter, over Setcases, near ski station, $42^{\circ} 25^{\prime} 30^{\prime \prime} \mathrm{N} 2^{\circ} 15^{\prime} 50^{\prime \prime}$ E, alt. 2000 m, 14 Sept 1983, J. Molero \& A. Rovira (BCN 4752).

— Huesca, Valle de Ordesa, 42 38' 06" N 0 00' 48" W, alt. 1700 m, 23 Jul 1992, J. Vicens, M. Bosch \& J. Simon (BCN). - Fig. 4G.

- Oviedo, Picos de Europa, Covadonga, Lago Enol, to Mirador del Rey, slits and meadows, 43 16' 19" N 4 59' 15" W, alt.1100 m, 2 Jun 1994, C. Blanché \& J. Simon (BCN). - Figs $2 \mathrm{E} \& 4 \mathrm{H}$.

- Zaragoza, Moncayo, Beratón, ravine slope, on stony and rich in humus ground near to A. lycoctonum, $41^{\circ} 43^{\prime} 17^{\prime \prime} \mathrm{N} 1^{\circ} 48^{\prime} 18^{\prime}$ 'W, alt. $1400 \mathrm{~m}, 2$ Jul 1995, J. Molero $(\mathrm{BCN})$. - Figs $2 \mathrm{~F} \& 4 \mathrm{I}$.

The obtained number for the seven studied populations is $2 n=4 \mathrm{x}=32$ chromosomes (Figs 2E- 2F), in agreement with the numerous previous counts (Bosch \& al. 2016). They are the first ones from the Iberian Peninsula. Some reports for A. napellus s.l. gave the somatic number $2 n=24$ for this taxon, coming from very old reports (Bosch \& al. 2016) or obtained from plants growing in botanical gardens; they probably belong to hybrids, as the example of $A$. napellus x A. variegatum cited by Seitz (1969).

We are also giving the haploid idiograms from four Iberian populations (Cantabric Mts, Pyrenees and Iberian System) (Figs 4F to 4I). The idiograms mainly match with the general model of $A$. napellus s.l. karyotypes proposed by Seitz (1969), with slight divergences in arm ratios (particularly pairs IV, V and VI) and distribution of satellites (either in pairs VII, X o XIII). The basic chromosome formula is $2 n=3 \mathrm{~m}+13 \mathrm{~m}(2 \mathrm{~m}+14 \mathrm{sm})=16$ chromosomes. 
1902. Aconitum variegatum L. subsp. pyrenaicum Vivant in Vivant \& Delay $-2 n=16$.

Ga: Pyrénées Atlantiques, Vallée d'Aspe, Espelunguère, near Ibón de Estanés, megaphorbic communities in limestone foot cliff, $42^{\circ} 48^{\prime} 21^{\prime \prime} \mathrm{N} 0^{\circ} 35^{\prime} 15^{\prime \prime} \mathrm{W}$, alt. 1650 m, 6 Oct 1995, J. Molero, P. Montserrat \& L. Villar (BCN 4754). - Fig. 4C.

Poorly known E Pyrenean endemic, we studied a population located very close to that published by Vivant \& Delay (1980), with the same result, $2 n=2 \mathrm{x}=16$ chromosomes.

Chromosome formula is $2 n=2 \mathrm{~m}+14 \mathrm{sm}=16$ chromosomes. The Fig. $4 \mathrm{C}$ shows the idiogram of $A$. variegatum subsp. pyrenaicum, with karyotype structure (except for the absence of satellite in pair III of the Pyrenean population) mainly sharing the data given by Seitz (1969) and Seitz \& al. (1972) from alpine German and Austrian populations of $A$. variegatum subsp. variegatum. All the reports belonging to subsp. variegatum (from Central Europe, Alps and Balkans) give $2 n=16$ (Bosch \& al. 2016), although some old counts indicate $2 n=24$ (Langlet 1927, Delay 1947).

\section{Acknowledgements}

We thank M. Antonieta Puig to help in the Laboratory work, and Josep Vicens, Luís Villar, Pere Montserrat, Felix Llamas, Bapha Fernández de Betoño and Juan Antonio Alejandre for providing material or information on plant locations.

Subsidized by Project PB.91-268 (DCIGYT, Ministerio de Educación y Ciencia, Spain) and Grant 2014SGR514 (Generalitat de Catalunya).

\section{References}

Akeroyd, J. R. \& Chater, A. O. 1993: Aconitum L. - Pp. 254-256 in: Tutin, T. G., Burges, N. A., Chater, A. O. Edmonson, J. R., Heywood, V. H., D. M. Moore, Valentine D. H., Walters, S. M. \& Webb, D. A. (eds), Flora Europea, 2nd Ed., 1. - Cambridge.

Baltisberger, M. \& Charpin, A. 1989: Chromosomenzählungen von Gilbert Boquet (f. 1986). - Ber. Geobot. Inst. ETH, Zürich 55: 246-261.

— \& Utelli, A. B. 2001: IOPB chromosome data 17. In: Kirschner, J., Drabkova L. \& Stace, A. C. (eds.). - Newslett. Int. Organ. P1. Biosyst. (Pruhonice) 33: 22-23.

Blanché, C., Molero, J., Bosch, M. \& Simon, J. 1997: La dysploïdie dans la tribu Delphinieae (Ranunculaceae). - Bocconea 5: 535-547.

Bosch, M., Simon, J., López-Pujol, J. \& Blanché, C. 2016: DCDB: an updated on-line database of chromosome numbers of tribe Delphinieae (Ranunculaceae). http://hdl.handle.net/2445/98702

Castroviejo, S., Cervera, M., Millanes, A. M. \& Novillo, M. 2003: Números cromosomáticos de algunas plantas mediterráneas. - Bol. R. Soc. Esp. Hist. Nat., Sec. Biol. 98(1-4): 9-19.

Delay, C. 1947: Recherches sur la structure des noyaux quiescents chez les Phanérogames. - Rev. Cytol. Cytophysiol. Vég. 9(1-4): 169-222.

Díez, M. J., Pastor, J. \& Fernández, I. 1984: Números cromosomáticos de plantas occidentales: $297-$ 306. - Anales Jard. Bot. Madrid 41(1): 191-194.

Galland, N. 1988: Recherche sur l'origine de la Flore orophile du Maroc. Etude caryologique et cytogeographique. - Trav. Inst. Sci., Sér. Bot. 35: 1-167. 
Hong, Y., Gao, Q., Luo, Y., Luo, J.-P., Zhang, Y., Yuan, Q. \& Yang, Q. 2016: Karyology of Aconitum subgenus Lycoctonum (Ranunculaceae) from China, with report of a new base chromosome number of $\mathrm{x}=6$ for the genus Aconitum. - Nordic J. Bot. 34(4): 441-454.

Jabbour, F. \& Jenner, S. 2012: A phylogeny of Delphinieae (Ranunculaceae) shows that Aconitum is nested within Delphinium and that Late Miocene transitions to long life cycles in the Himalayas and Southwest China coincide with bursts in diversification. - Mol. Phylogen. Evol. 62: 928-942.

Kočková, L. 2012: Genome size \& genomic base composition in Ranunculaceae. - Master's Thesis Disertation, Masarykova Univerzita. - Brno.

Küpfer, P. 1974: Recerches sur les liens de parenté entre la flore orophile des Alpes et celle des Pyrénées. - Boissiera 23: 3-322.

Langlet, O. F. 1927: Beirträge zur Zytologie der Ranunculazeen. - Svensk Bot. Tidskr. 21(1): 1-17.

Löve, Å. \& Kjellquist, E. 1974: Cytotaxonomy of Spanish plants III. Dycotiledons: Salicaceae Rosaceae. - Lagascalia 4(1): 3-32.

Lovka, M., Susnik, F., Löve, Å. \& Löve, D. 1971: Reports. [In Löve, Å (ed.) IOPB chromosome number reports XXXIV]. - Taxon 20(5/6): 785-797.

Molero, J. \& Blanché, C. 1986: Aconitum L. - Pp. 233-242 in: Castroviejo, S., Laínz, M., López González, G. Montserrat, P., Muñoz Garmendia, F., Paiva, J. \& Villar, L. (eds), Flora Iberica, 1. - Madrid.

Romero, C. 1986: A new method for estimating karyotype asymmetry. - Taxon 35(3): 526-530.

Schafer, B. \& La Cour, L. F. 1934: A chromosome survey of Aconitum, I. - Ann. Bot. 191(48): 693-713. Seitz, W. 1969: Die taxonomie der Aconitum napellus Gruppe in Europa. - Feddes Repert. 80(1): 1-76.

—, Zinsmeister, D. \& Abicht, M. 1972: Beiträge zur systematik der Gattung Aconitum in Europa. Bot. Jahrb. Syst. 92(4): 490-507.

Vivant, J. \& Delay, J. 1980: Sur quelques endémiques pyrènéennes. Citotaxonomie, II. - Bull. Soc. Bot. France 127(5): 493-505.

Yuan, Q. \& Yang, Q. E. 2006: Polyploidy in Aconitum subgenus Lycoctonum (Ranunculaceae). Bot. J. Linn. Soc. 150(3): 343-353.

Address of the authors:

Julià Molero, Ana M. Rovira, Maria Bosch, Joan Simon \& Cèsar Blanché,

BioC (GReB) \& IRBio, Laboratori de Botànica, Facultat de Farmàcia, Universitat de Barcelona, Av. Joan XXIII s/n, 08028-Barcelona, Catalonia (Spain). E-mail: mariabosch@ub.edu 